INTERDISCIPLINARIA ARCHAEOLOGICA NATURAL SCIENCES IN ARCHAEOLOGY

Thematic review

\title{
Advances in Archaeological Soil Chemistry in Central Europe
}

\author{
Roderick B. Salisbury ${ }^{\mathrm{a}, \mathrm{b}^{*}}$ \\ ${ }^{a}$ Department of Prehistoric and Historical Archaeology, University of Vienna, Franz-Klein-Gasse 1, 1190 Vienna, Austria \\ ${ }^{b}$ OREA Institute for Oriental and European Archaeology, Austrian Academy of Sciences, Hollandstrasse 11+13, 1020 Vienna, Austria
}

\section{A RTICLE INFO}

\section{Article history:}

Received: $9^{\text {th }}$ September 2020

Accepted: $27^{\text {th }}$ November 2020

DOI: http://dx.doi.org/10.24916/iansa.2020.2.5

\section{Key words:}

archaeological soil chemistry

archaeological prospection

settlement patterns

activity areas

Central Europe

\begin{abstract}
A B S T R A C T
Analytical technologies for the evaluation of archaeological soils have developed rapidly in recent decades, and now support a range of innovative research and interpretations of archaeological sites and landscapes. Established methods, including phosphates and multi-element ICP-MS/OES, have provided interpretations of the use of space within settlements and houses, and the function of specific archaeological features. Recently, portable X-Ray Fluorescence has been introduced to archaeological soil science, but published results have generated knowledge gaps. The correspondence between archaeological geochemical anomalies and specific human activities is partly dependent on geology (including sediment type and relative acidity and permeability of the soil), topography, and formation processes, as well as influence of human activities. At the same time, which elements, and fractions of elements, are measured is largely dependent on instrument parameters and extraction methods. This paper provides an overview of archaeological soil chemistry in Central Europe, and the current state-of-the-art, followed by an assessment of future developments in archaeological soil chemistry, molecular biogeochemistry, and the significance of geoarchaeology in multi-disciplinary research.
\end{abstract}

\section{Introduction}

Soils and sediments are archaeological materials, archaeological resources that contain an archive of past events and cultural behaviours. For nearly one hundred years, archaeologists and soil scientists have accessed parts of this archive through applications in archaeological soil chemistry. Central Europe has been home to several key developments in archaeological soil chemistry, from the earliest applications of soil phosphate analysis to recent practical application of portable X-ray Fluorescence spectroscopy. Established methods, including phosphate analyses and multi-element ICP-MS/OES, have provided interpretations of the use of space within settlements and houses, and the function of specific archaeological features. As archaeology continues to evolve as a discipline, microremains are becoming increasingly important sources of data about past human mobility, diversity, production, consumption, and human ecodynamics. These data come from a range of sources, including both human and animal

\footnotetext{
*Corresponding author. E-mail: roderick.salisbury@univie.ac.at
}

remains, primarily bones and teeth (proteomics, Charlton et al., 2019; strontium isotopes, Giblin et al., 2013), and portable artefacts (e.g. starch grains on grinding stones and ceramics, Duke et al., 2018; ceramic residue analysis Dunne, et al., 2019; residues on lithics, Rots et al., 2015).

Chemistry of soils and sediments have been recognized, and utilized, for a longer time. In addition to soil phosphate analysis, soil chemical methods for archaeology traditionally include multi-element chemistry, soil $\mathrm{pH}$, magnetic susceptibility, and soil organic carbon and nitrogen. Recently, research in the Central European Palaeolithic have combined these, for example, assessing carbon, nitrogen, and magnetic susceptibility at the Pod Hradem cave to aid in interpreting soil formation and potential climatic changes (Nejman et al. 2018; 2020). Nevertheless, full exploitation of the soil archive remains sporadic.

Cultural soilscapes (Salisbury, 2016; Wells, 2006) hold ancient human and environmental DNA (Slon et al., 2017; Willerslev et al., 2003), biomarkers (Kovaleva and Kovalev, 2015; Zocatelli et al., 2017), traces of pollution (Martínez Cortizas et al., 2016; Veron et al., 2014), evidence of ecological changes and the environmental impact of 
cultural behaviour (Schumacher et al., 2016; Sprafke, 2016), archaeological site formation processes (Nicoll and Murphy, 2014), raw material provenance for components of ceramic matrices (Riebe and Niziolek, 2015), and the contamination of cultural heritage and artefacts by modern pollution (Nord et al., 2005). Continued development of archaeological biogeochemistry is beginning to recognize the archaeological potential of proteomics, genomics, and other biomarkers in the soil archive.

Several reviews of archaeological sol chemistry have been published (Oonk et al., 2009a; Wilson et al., 2008); of especial import was the detailed summary of soil phosphate methods in archaeology by Holliday and Gartner (2007). A vast body of literature exists for archaeological soil chemistry (Table 1). This review of the history and development of archaeological soil chemistry focuses on examples from Central Europe, and the current state-of-the-art, followed by an assessment of future developments in molecular biogeochemistry and the significance of geoarchaeology in multi-disciplinary research. Currently, trends are changing from the traditional roles of archaeological soil chemistry - site prospection and delimiting habitation areas - into a complex, multidisciplinary endeavour integrating various strands of geoarchaeology, bioarchaeology, and environmental studies. This trajectory needs geoarchaeologists to contribute to diachronic and synchronic examinations of archaeological landscapes and human-ecodynamics.

\section{Archaeological soil phosphates in Central Europe}

The history of archaeological soil chemistry extends over a century (Arrhenius, 1931) and across the globe, from Alaska (Knudson et al., 2004) to the Levant (Šmejda et al., 2018) and to Australia (Fanning et al., 2018). The link between ancient human occupation and increased soil phosphate content were first noted in late $19^{\text {th }}$ or early $20^{\text {th }}$ century agricultural soil surveys (Russell, 1915). Publication of methods and results began when Swedish agronomist Olaf Arrhenius recognized and recorded the relationship between surface finds, human occupation, and soil phosphate levels while conducting agricultural soil testing, and posited a causal correlation between enhanced soil phosphates and human settlements (Arrhenius, 1929; 1931). The method was applied to Swedish habitation sites by Schnell (1932), who sampled along transects radiating outward from an assumed

Table 1. Selected references for archaeological soil chemistry, with focus on Central Europe (arranged chronologically).

\begin{tabular}{|c|c|}
\hline Type of study & References \\
\hline Soil chemistry \& soil science & $\begin{array}{l}\text { Feigl, 1960; Bowen, 1979; Füleky, 1983; Kabata-Pendias and Pendias, 1984; Sposito, 1998; } \\
\text { Sparks 1996; 2003; Holliday 2004. }\end{array}$ \\
\hline Early archaeological investigations & $\begin{array}{l}\text { Arrhenius, 1929; 1931; Lorch, 1930; 1940; 1941; 1951; Schnell, 1932; Christensen, 1935; Bandi, } \\
\text { 1945; Stoye, 1950; Lutz, 1951; Dauncy, 1952; Pelikán, 1954; Dietz, } 1957 .\end{array}$ \\
\hline Methdological reviews and histories & $\begin{array}{l}\text { Sjoberg, 1976; Eidt, 1977; Keeley, 1981; Bethell and Máté, 1989; Zölitz and Heinrich, 1990; } \\
\text { Walker, 1992; Kondratiuk and Banaszuk, 1993; Bjelajac et al., 1996; Aston et al., 1998; Klamm } \\
\text { et al., 1998; Leonardi et al., 1999; Haslam and Tibbett, 2004; Wells 2004a; Holliday and Gartner, } \\
\text { 2007; Wilson et al., 2008; Oonk et al., 2009a; Pastor et al., 2016. }\end{array}$ \\
\hline
\end{tabular}

\begin{tabular}{ll}
\hline \multicolumn{1}{c}{ Applications in Central Europe } \\
\hline Phosphate & Gundlach, 1961; Schwarz, 1967; Grimm, 1971; Sjöberg, 1976; Kiefmann, 1979; Zölitz, 1980; \\
1982; 1983; 1986; Gebhardt, 1982; Majer, 1984; Zimmermann, 1995; 2001; 2008; Stäuble and \\
Lüning, 1999; Majer, 2004; Sarris et al., 2004; Ernée, 2005; Ernée and Majer, 2009; Hlavica \\
et al., 2011; Schreg and Behrendt, 2011; Petř́k et al., 2012; Salisbury, 2012; Lauer et al., 2013; \\
Salisbury et al., 2013; Weihrauch et al., 2017; Weihrauch and Söder, 2020; Weihrauch et al., 2020. \\
Hejcman et al., 2011; 2013a; 2013b; Gauss et al., 2013; Salisbury, 2013; Pető et al., 2015; Lubos \\
et al., 2016; Salisbury, 2016; Dreibrodt et al., 2017; Smejda et al., 2017; 2018; Horák et al., 2018; \\
Julti-element
\end{tabular}

\section{Future directions}

\begin{tabular}{ll}
\hline Lipid biomarkers & Bull et al., 2000; Bull et al., 2002; Schwark et al., 2002; Killops and Killops, 2005; Zech et al., \\
& 2010; Schatz et al., 2011; Sistiaga et al., 2014; Prost et al., 2017; Zocatelli et al., 2017; Harrault \\
& et al., 2019; Schirrmacher et al., 2019; Patalano et al., 2020; Portillo et al., 2020.
\end{tabular}

Isotopes Bogaard et al., 2007; D’Anjou et al., 2012; Abell et al., 2019; Bataille et al., 2020; Snoeck et al., 2020.

Sediment aDNA

Hebsgaard et al., 2009; Giguet-Covex et al., 2014; Madeja, 2015; Thomsen and Willerslev, 2015; Parducci et al., 2017; Slon et al., 2017; Brunson and Reich, 2019; Epp et al., 2019; Nejman et al., 2020.

Proteomics Oonk et al., 2012. 
central point in a given site and constructed isopleth maps of the phosphate values to delimit site boundaries. Following this, archaeologists in Central Europe and elsewhere have conducted soil phosphate analyses for archaeological survey and site interpretations for nearly a century, with continuing methodological developments.

Early archaeological soil chemistry focused primarily on phosphates for four reasons: First, it was the first element explicitly connected to prehistoric human habitation, and subsequent studies exploited this discovery. Second, it is essential to life and therefore can be found in and deposited by anything organic, as primary, secondary, or in situ refuse. Inputs include food preparation wastes such as bone, meat, fish, and plants, wood ash, human or animal burials, and urine and faeces of humans and animals. Therefore, human habitation areas will have higher levels of soil $\mathrm{P}$ than surrounding areas with no habitation. Conway (1983) demonstrated that human occupation could result in annual increases in concentrations of P from 1-10\%. Third, phosphates tend to accumulate quickly, have low solubility and a strong ability to fix within the soil profile. In favourable soil conditions, P remains stable and is likely to be retained, even in disturbed soils, for millennia without appreciable leaching. Fourth, in its most basic form, phosphate testing is fast and inexpensive compared with almost every other analytical technique, and can be conducted in the field during survey or excavation.

\subsection{The first 60 years of archaeological soil phosphate analysis}

Arrhenius's methods were quickly applied to prehistoric and medieval sites in Central Europe by German geographer Walter Lorch $(1940 ; 1941 ; 1951)$. Lorch sampled along regular transects across and around ancient settlements, used a laboratory colorimetric method to measure phosphate content, and graphed the results. By comparing graphs of density and distribution, and interpreting the different profiles, Lorch persuasively argued that variability in phosphate was due to different subsistence economies in the Palaeolithic, Neolithic, and metal ages. Other research projects soon followed. Bandi (1945) used Lorch's method to locate a medieval site in Switzerland. Dietz (1957) used a method of sulphuric acid in test tubes visually compared to standards to examine a small plot of land with surface material indicating prehistoric activity, looking for evidence of organic waste deposits.

The next major advance in archaeological soil phosphate studies came with the development of a spot-test, or ringchromatography test, by Friedrich "Fritz" Feigl in Vienna. In his comprehensive two-volume compendium on chemical spot-tests, Feigl (1960) recommended the highly toxic and corrosive nitric acid $\left(\mathrm{HNO}_{3}\right)$ to prepare an ammonium molybdate solution, and the toxic and flammable benzidine as a reducing agent to measure inorganic phosphate from geological samples. Gundlach (1961) modified Feigl's method to increase the speed and safety when testing soil from boreholes at prehistoric sites. Gundlach retained the nitric acid for digestion, but switched to the organic and relatively harmless ascorbic acid $\left(\mathrm{C}_{6} \mathrm{H}_{8} \mathrm{O}_{6}\right)$ for reduction, making it more stable and eliminating the need for flame and ammonia in field conditions. In any acid-molybdate method, $\mathrm{PO}_{4}$ reacts with molybdate to form phosphomolybdic acid (yellowish in colour); in Gundlach's method, phosphomolybdic acid is reduced by ascorbic acid to form a blue complex. Gundlach conducted his tests in the field, with the filter paper and drop bottles attached to a pole stuck in the ground next to his borehole (depicted in Gundlach, 1961 p.736, Figure 1), and noted that the entire process takes approximately 90 seconds. Gundlach ranked the results on a scale of $1-5$, from none to very high levels of $\mathrm{P}$.

Schwarz (1967) used the Gundlach method and established a field methodology for sample collection, collecting samples in plastic bags, collecting enough soil to run multiple tests and to determine colour and grain size, and collecting samples by layer. Schwarz conducted large-scale surveys near the San Bernardino Pass in southern Switzerland, taking samples at $30-50 \mathrm{~m}$ intervals. Two suggestions regarding research methodology are of note from the Schwarz's paper. First, he observed that some information about land-use, previous archaeological investigations, and geomorphology are essential to planning a chemical survey campaign. Second, he suggested that phosphate surveys would be more useful when complemented by geophysical surveys or test trenching, and warned that carrion pits, where local villagers dispose of diseased animals, should not be mistaken for prehistoric habitations (Schwarz, 1967, pp.58-61). Schwarz's sampling approach has been criticized (Sjöberg, 1976, p.449) because of his suggestion that samples be taken along natural lines, such as field boundaries, rather than on a regular grid or transect system.

Kiefmann(1979) conducted large-scale phosphate mapping in East Holstein and arrived at two significant conclusions. First, soil phosphate content is influenced by both changing land-use and pedogenesis. That is, archaeological soil chemistry requires some understanding of both cultural and non-cultural formation processes, including soil formation. Second, Kiefmann found that different extraction methods yielded different $\mathrm{P}$ concentrations and distributions.

Zölitz (1980) pioneered the use of variogram modelling as a statistical method for analysing soil phosphate results. Majer (1984) developed a 3-point relative scale for measuring results, and noted that archaeologists were most interested in the anthropogenic enhancement of soil phosphate, rather than the total quantity of P. Phosphate surveys successfully identified residential areas in both prehistoric and medieval sites (Grimm, 1971; Zölitz, 1982; 1983; 1986).

Eidt refined Gundlach's method further, first by replacing nitric acid with hydrochloric acid ( $\mathrm{HCl})$ (Eidt, 1973) and then by developing a bath to stop the chemical reaction, so that results could be archived (Eidt, 1977). Eidt found that $\mathrm{HCl}$ is superior to both nitric acid and sulphuric acid when extracting $\mathrm{P}$ in laboratory tests, and observed that the use of $\mathrm{HCl}$ for both field and lab analyses would improve comparability of results. He also noted that the question of 
which acid was superior in most cases had been raised by both Feigl (1960) and Murphy and Riley (1962), and the answer was probably that both nitric and sulphuric acids are oxidizers, whilst producing a blue colour from phosphate and molybdenum requires a reducing process (Eidt, 1973, p.207).

By the 1990s, spot-test methods were standardized, a few specific extraction formulas for colorimetry had been widely adopted, and several critiques and reviews were being published (Bethell and Máté, 1989; Bjelajac et al., 1996; Klamm et al., 1998; Kondratiuk and Banaszuk, 1993; Zölitz and Heinrich, 1990). In Germany and in the Czech Republic, soil phosphate analyses were frequently used (Majer, 2004; Stäuble and Lüning, 1999; Zimmermann, 1995), but were rarely used elsewhere in Central Europe.

\subsection{Recent developments of soil phosphate analysis in Central Europe}

Despite acknowledgement of the contribution of soil phosphate mapping for settlement archaeology (Zimmermann, 2001), the increasing sophistication of aerial remote sensing and geophysical prospection led to wide-scale adoption of alternative survey methods at both the site and regional scale, and a concomitant decrease in soil chemistry survey. In part, this can be explained by recognizing that phosphate spot testing, the method fastest and requiring the least training and financing, is also the least informative method; Zimmerman (2001) called it inappropriate. As a survey method, inappropriate is perhaps unfair for a tool that identifies areas of possible human settlement activity while enabling students to participate in sample collection and analysis during field projects. Archaeological soil phosphate has been the largest and most common application of geochemistry in archaeology, with examples at the regional and micro-regional scales (Nuñez and Vinberg, 1990; Salisbury, 2012; Thurston, 2001; Zölitz, 1982). Challenges remain, however, including fertilization (Weihrauch et al., 2017) and heterogeneous environments (Weihrauch and Söder, 2020).

Although an essential component of site prospection and settlement archaeology, soil phosphate analysis is largely restricted to identifying activity or habitation areas where large quantities of organic matter were deposited, such as detecting boundaries of settlements, household clusters, and activity zones (Salisbury, 2016; Sarris et al., 2004; Zimmermann, 2008). Pav (available P) was used to delineate site boundaries at a series of Late Neolithic and Early Copper Age settlements in the Körös Region of eastern Hungary (Figure 2; Salisbury, 2012; 2016).

$\mathrm{P}$ analysis was applied at the excavation of an early medieval house at Schalkstetten in South Germany. Samples from a $1 \mathrm{~m}$ interval grid revealed three areas of elevated P. One

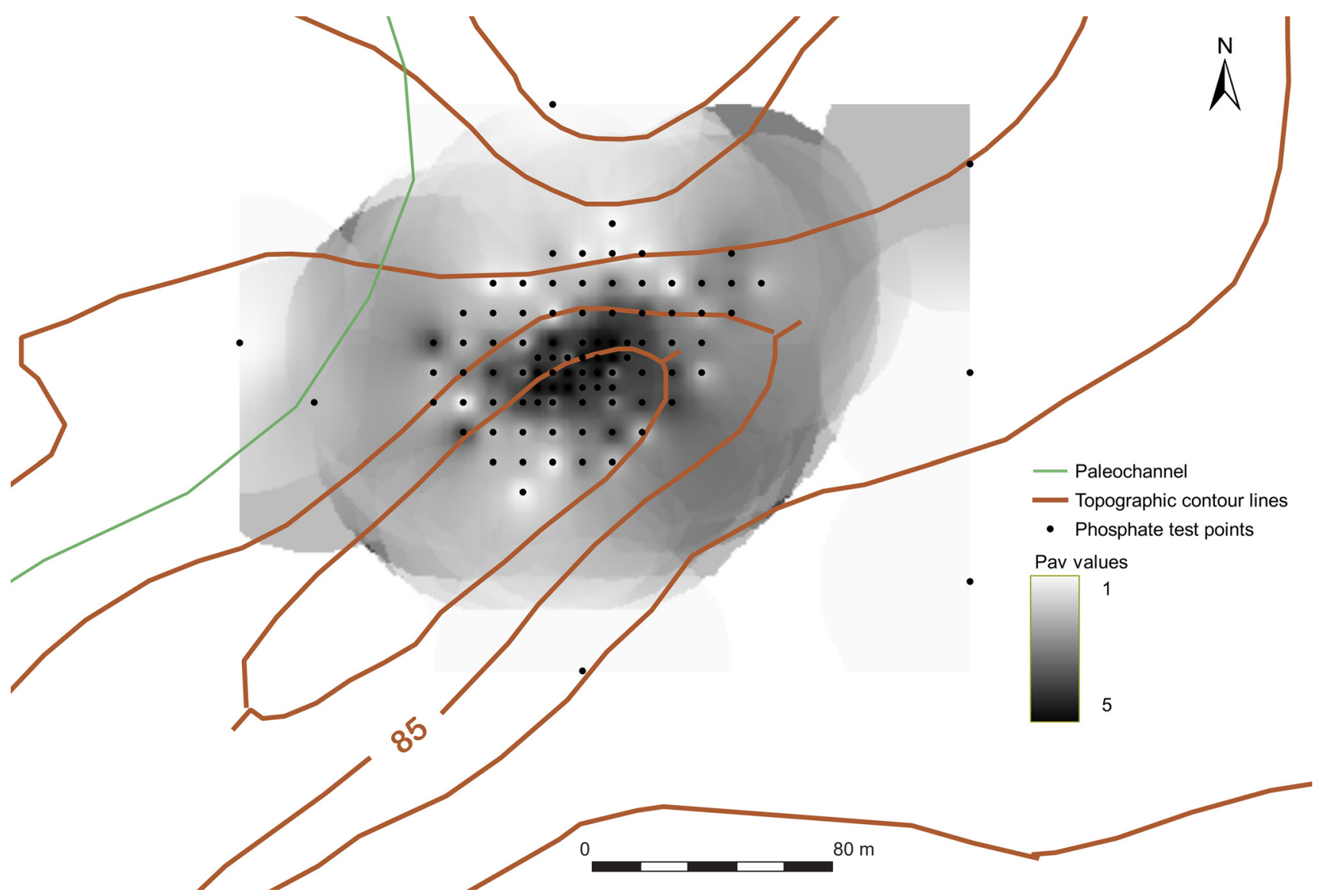

Figure 1. Distribution of Pav (available P) at the Early Copper Age Tiszapolgár settlement of Mezöberény-68 on an elevated loess ridge on the south side of a palaeochannel in the Körös Region of eastern Hungary. 
of these areas was associated with a hearth and interpreted as indicating food preparation. The other two areas could not be interpreted with certainty, although knowledge of typical organization of medieval houses into domestic areas and stables led to a plausible conclusion that a large area of $\mathrm{P}$ enrichment on one end of the structure marked the stable (Schreg and Behrendt, 2011). In another example, soil $\mathrm{P}$ was successful in delimiting vertical stratigraphy and layers with anthropogenic inputs, even when those layers could not be distinguished visually (Ernée, 2005). Ongoing developments in soil $\mathrm{P}$ analysis in Central Europe indicate that the method not only remains useful, but has the potential to overcome some restrictions - for example, through the use of oxalate-extractable $\mathrm{P}$ (P-ox) as an alternative to phosphate fractionation (Weihrauch et al., 2020).

In the Czech Republic phosphate analysis has a long history of use for analysing cemeteries and possible burials. Early research focused on using soil $\mathrm{P}$ to aid in identifying graves with poor or no bone preservation (Pelikán, 1954), including the identification of elevated $\mathrm{P}$ in cremation burials (Págo 1963, cited in Petř́k et al., 2012). More recently, phosphate analysis was combined with the Brongers method of identifying wood remains at a Bell Beaker site in Moravia (Hlavica et al., 2011). At the Bronze Age Únětice site of Prague 9 - Miškovice site, phosphate anomalies in the form of burials aided in identifying grave-pits as a third burial form (along with inhumations and cenotaphs); cenotaphs lacked any P enrichment (Ernée and Majer, 2009). Similar results were obtained from Bell Beaker burials at several sites in the Znojmo district in Moravia (Petřík et al., 2012). In that study, researchers also identified potential complications arising from various formation processes, including the influence of burial in or on wood, which apparently produced a lower signature than bodies placed directly on soil, and elevated $P$ values associated with a secondary intrusion of organic sediments.

Phosphate testing is most effective when used as one component of an integrated multi-proxy approach to regional prospection and site investigations. In Hungary, soil P is used along with magnetic survey, magnetic susceptibility, and surface collection to identify vertical and horizontal limits of Neolithic and Copper Age settlements, and the extent of settlement and activity areas within micro-regions (Gyucha et al., 2015; Parkinson et al., 2010; Salisbury et al., 2013; Sarris et al., 2004). Phosphorus was used as one proxy in a multi-proxy reconstruction of functional spaces at a Late Bronze Age farmstead in Poland (Markiewicz and Rembisz-Lubiejewska, 2016).

\section{Multi-element soil chemistry}

Lutz (1951) recognized in the 1950s that elements other than $\mathrm{P}$ could be useful in archaeological contexts. Multielement geochemistry provides more detailed information about what people did and where they did things, because human activities alter all the chemical and physical properties of soils. Within archaeology, multi-element analyses have increasingly been applied for identifying different activity areas in connection with settlements, craft production, and marketplaces (Coronel et al., 2015; Holliday et al., 2010; Salisbury, 2017). The elements most often found to be associated with human settlements are $\mathrm{P}$, $\mathrm{K}, \mathrm{Ca}, \mathrm{Mn}, \mathrm{Cu}, \mathrm{Zn}, \mathrm{Sr}, \mathrm{Ba}$ and $\mathrm{Pb}$, but elements such as $\mathrm{Mg}$, $\mathrm{Rb}, \mathrm{Cs}$ and Th have also proven useful in some instances (Entwistle et al., 2000; Oonk et al., 2009a; Wilson et al., 2008; 2009). Archaeological applications of multi-element soil chemistry have typically used ICP-MS; portable X-ray fluorescence is now being adopted and adapted (Coronel et al., 2014; Gauss et al., 2013; Šmejda et al., 2017).

Much of what we know about the relationship between these elements and human activities comes from ethnographic studies, where human behaviour is observed and analyses conducted to see how this behaviour affects the soil chemistry. Ethnoarchaeological studies working with indigenous people in their households in small, rural villages have been done in Central America, including Oaxaca (Middleton and Price, 1996), several other areas in Mexico (Barba and Ortiz, 1992; Barba et al., 1996), Guatemala (Fernández et al., 2002; Terry et al., 2004), and Honduras (Wells and Urban, 2002). These studies found connections between specific domestic activities, such as cooking, storage and crafting, and specific chemical elements, compounds, and soil properties. There are also a few examples from arctic and subarctic regions (Butler et al., 2018; Knudson and Frink, 2010), but few from temperate Europe. This means that these studies occur on soil types that do not include loess, and focus on a specific set of input materials, some of which, like maize, did not exist in prehistoric and early historic Europe. Carbon (C) and Nitrogen $(\mathrm{N})$ are also important elements to consider, especially in terms of depletion due to agriculture, or enrichment through fertilization, but these elements are too light to be analysed using either ICP-MS or XRF, so their investigation requires other instrumentation to be employed. A key point here is the gap in our knowledge base, which can only be closed by experimental and ethnoarchaeological research in Central Europe.

Multi-element work is almost exclusively restricted to excavation contexts, where we already have a potential archaeological interpretation and want confirmation, or when we try to interpret "empty" places (Terry et al., 2015). Analysis of a paleosol from beneath a Bell Beaker (c. 2500-2200 BC) burial mound in Moravia indicated that the burial location had not been used for habitation or production activities (Hejcman et al., 2013b). In part, identification of the paleosol was based on levels of lead and cadmium lower than surrounding soils. In rare occasions, multi-element chemistry has been used to interpret unexcavated areas. For example, Principal Components of multi-element data from Late Neolithic and Early Copper Age farmsteads in eastern Hungary were interpreted to delineate potential activity zones, and compared to identify similarities in the use of space (Salisbury, 2013; 2016). 
Multi-element soil chemistry has also been used to determine archaeological context as a primary factor for the appearance of cropmarks. In a series of papers, Hejcman and colleagues demonstrated that the chemical composition of ancient pit fills, subsoils, surface soils and vegetation was directly enhanced by the presence of ancient human activities (Gojda and Hejcman, 2012; Hejcman et al., 2011; Hejcman and Smrž, 2010; Hejcman et al., 2013a). In particular, the analysis of ashed vegetation from assumed archaeological features (positive cropmarks) and "background" vegetation enabled a straightforward correlation between anthropogenic chemical enrichment and the effectiveness of aerial archaeology (Gojda and Hejcman, 2012).

\subsection{Extraction processes}

By comparing the relative concentrations and combinations of elements, as well as other soil components (e.g. $\mathrm{pH}$, soil organic content, and magnetic susceptibility), activity patterns can be identified and examined (Pető et al., 2015; Pető et al., 2019; Salisbury, 2013). We use relative concentrations because many variables affect elemental levels in soils, and we are specifically looking for anthropogenic inputs (Wells et al., 2000; Wells et al., 2007). This focus on anthropogenic inputs has also resulted in broad disparities in analytical methods.

These disparities lead to a second knowledge gap, one that has been noted several times (Oonk et al., 2009b; Pastor et al., 2016; Wilson et al., 2006). Despite advances in sample preparation and analytical methods, we still lack standardized protocols, or a fundamental agreement on how sediment characteristics and laboratory condition influence our extraction methods and subsequent results. In addition, meta-studies investigating the efficacy of methods and comparability of results are largely lacking (but see Lubos et al., 2016). The type of extraction used will highly influence the results. Americanist archaeologists frequently rely on a weak-acid extraction that is intended to extract only the anthropogenic signature (Middleton, 2004; Salisbury, 2016; Wells, 2004). In the experience of this author, geologists are horrified by this approach, arguing that total extraction using strong acids at high temperature is the only acceptable method. Both can be made to sound like reasonable arguments, but each might be inappropriate for archaeology. Geoarchaeologists have developed alternatives that give quasi-total extraction. One example using $\mathrm{HNO}_{3}$ is set out in Wilson (2008). Mehlich 3 extractant is widely used in the Czech Republic, and has been recommended as an international standard for archaeological soil chemistry (Hejcman et al., 2013b).

Attempts at standardization are unlikely to be a perfect solution, because the extractions should be based partly on methodological consistency and comparability, but also on regional soils, environmental conditions, and the nature of the elements themselves (Pastor et al., 2016; Wilson et al., 2006). Therefore, reliability and comparability will be better served by consistent standardization in sample handling and preparation, documentation of methods and protocols, and presentation of results.

\subsection{Portable XRF - a new state-of-the-art}

Portable, handheld, energy dispersive X-ray Fluorescence spectroscopy ( $\mathrm{pXRF}$ ) is comparatively inexpensive, nondestructive, and enables rapid acquisition of large datasets, and therefore is rapidly being adopted for a range of archaeological applications (Holcomb and Karkanas, 2019; Michałowski et al., 2020; Riebe, 2019; Vianello and Tykot, 2017). Technological innovations are solving many of the problems confronted by early adopters, such as the inability to measure $\mathrm{P}$ and other light elements, and the interference of silicon with P (Coronel et al., 2014). Handheld XRFs are now being widely used for soil analyses, in Central Europe and elsewhere (Dreslerová et al., 2020; Horák et al., 2018; Lubos et al., 2016; Šmejda et al., 2017). In addition, pXRF returns total elemental composition, making it comparable to total and quasi-total chemical extractions.

At the fortified Early Bronze Age settlement of Fidvár in southwest Slovakia, pXRF analysis of samples from an Early Bronze Age house, the site centre, a potential metal workshop, and the fortification ditch indicated $\mathrm{P}$ enrichment in the ditch and low levels in the house. Calcium and strontium varied within house samples, and were again higher in the ditch. No geochemical evidence for metalworking activities were found (Gauss et al., 2013). Using a similar methodology, 74 samples were analysed from a Neolithic Linear Pottery Culture house and associated ditch near Vráble in Slovakia. Results indicated the need to consider post-depositional processes, in this case in bio-cycling in particular, for accurate interpretations (Dreibrodt et al., 2017).

Medieval settlements have also received attention. At the abandoned medieval village of Lovětín near Třešt' in western Moravia, general household waste was likely spread on agricultural plots, based on elevated levels of $\mathrm{Mn}, \mathrm{Sr}$, and K. Corresponding low levels of $\mathrm{P}$ were interpreted as $\mathrm{P}$ depletion due to ineffective fertilization; widespread use of manuring was not evident. Nevertheless, the authors cautioned that the detection limits of their instrument constrained measurements of $\mathrm{P}$ and $\mathrm{Ca}$ (Horák et al., 2018).

Portable XRF has also been applied to cemetery research. In a Late Bronze Age and Early Iron Age example, pXRF was used to determine that urn cenotaphs - burial urns with no macroscopic bone remains inside - never contained bones (Pankowská et al., 2018). Fill of urns without bones had lower levels of $\mathrm{P}, \mathrm{Ca}, \mathrm{Mn}, \mathrm{Zn}, \mathrm{Pb}$ and $\mathrm{V}$ when compared to samples from urns containing visible bone fragments.

Effective application of portable X-ray fluorescence analysis in the field, to establish multi-element chemical analyses as a standard approach in archaeological fieldwork, requires a workflow optimized for field conditions. The optimal ex situ methodology, wherein sediment samples are oven dried, milled to c. 20 microns, homogenized, and pressed into pellets or disks, clearly remove many factors that influence measurements, such as sunlight, soil moisture content, and measuring a single large particle in un-sieved, un-homogenized sediments. However, transportation, storage, and laboratory processing remove the advantages of a portable, affordable instrument that provides results in 
one day. Conversely, in situ methods that take full advantage of portability and speed by directly measuring sediments at the surface (Šmejda et al., 2017; Šmejda et al., 2018) do not always produce reliable and replicable data on the elemental composition of a sampled context (Goff et al., 2020). Nevertheless, in field analyses will be conducted, because of the obvious advantages. Therefore, establishing a protocol for in field testing, particularly for consistent sample preparation, is essential (Frahm et al., 2016; Goff et al., 2020). The best alternative for in field analysis is sampling, air-drying, sieving through $2 \mathrm{~mm}$ mesh, crushing and homogenizing by hand using ceramic mortars and pestles, and packing into plastic sample cups covered with thin polypropylene or mylar film (cf. Dreibrodt et al., 2017; Goff et al., 2020).

Unlike the situation of various extraction methods for ICPOES/MS, serious attention has been given to the question of how pXRF results compare to ICP-based analyses (Frahm et al., 2016; Gauss et al., 2013; Lubos et al., 2016). For the most part, results are comparable when total or quasitotal extraction methods are used. The primary purpose of archaeological soil chemistry is to establish patterns of activities rather than absolute elemental values. Therefore, the most important comparison is of the spatial patterning of element enrichment and depletion, which is less frequently reported. The study by Lubos and colleagues (2016) is an important exception to many critiques; comparison of several strong acid and weak acid extractions with pXRF indicates high correlation of results using weak $\mathrm{HCL}$, strong $\mathrm{HNO}_{3}$, Aqua Regia (all ICP-OES), and pXRF.

Moreover, the accuracy and reproducibility of measurements depend on instrument calibration, availability of appropriate material standards, and regular measurement of blanks (e.g. $\mathrm{SiO}_{2}$ blanks). Three sets of calibrations for soil analysis are available from major pXRF models. Although each company uses different names for these, they can be grouped as an empirical mode (requiring known samples), fundamental parameters (FP), and Compton normalization. The latter two come preinstalled; recent models often include a combined fundamental-Compton mode. International soil and sediment geological standards (GBW 7411, NIST 2780, NCS 73308, TILL-4, and USGS SdAR-M2) might be problematic, particularly in areas of redeposited loess, such as the Great Hungarian Plain. For example, TILL-4 is a sample of till taken in New Brunswick, Canada; NIST 2780 is hard rock mine waste. Correction of reported pXRF data with local calibration samples can resolve these issues (Goff et al., 2020), but local calibration samples must be developed for each region and geology.

\section{Future directions}

Following the third-science revolution (Kintigh et al., 2014; Kristiansen, 2014), issues of mobility and migration, increasing complexity in social and settlement organization, human-environmental interactions, economic sustainability, and cultural and environmental resilience are becoming increasingly relevant for archaeology. In spite of the unremarkable fact that most human activities generate measurable traces in sediments, plasters and other surfaces, these papers do not specifically mention the role of geoarchaeology. In addition to the continued development of multi-element sediment geochemistry, biogeochemistry is providing new insights into questions about mobility, domestication, land use, anthropogenic impacts, and sociopolitical interactions. This section will briefly examine some recent developments in these arenas, with contributions from geoarchaeology and soil science.

Biogeochemistry is a highly inter-disciplinary concentration on cycles of chemical elements and their isotopic ratios, and natural or anthropogenic organic compounds such as proteins, lipids, carbohydrates, and nucleic acids. Organic molecules from biological sources can be preserved in soils and sediments, and serve as markers of anthropogenic activity, although the preservation of these biomarkers is highly dependent on the pedological conditions (Bull et al., 2000; Bull et al., 2002; Killops and Killops, 2005). Soil biomarkers have been used, albeit sporadically, to aid reconstructions of palaeoenvironmental conditions, cultivation and manuring, and other human activities at multiple analytical scales (Bethell et al., 1994; Hjulström and Isaksson, 2009; Prost et al., 2017; Simpson et al., 1999).

Faecal biomarkers, in particular $5 \beta$-stanol lipids, provide data on pastoral practices and land-use in France (Zocatelli et al., 2017), animal husbandry and uses for dung in Anatolia (Portillo et al., 2020), and plants as a significant component of Neanderthal diet in Spain (Sistiaga et al., 2014). Faecal biomarkers can now be used to distinguish between different animal species (Harrault et al., 2019; Prost et al., 2017), significantly increasing their usefulness for research on early domestication and animal husbandry.

Lipid biomarkers from plants, in the form of plant sterols and $n$-alkanes from leaf waxes, are chemically inert, persist in sediments for thousands of years or more, and provide direct evidence of vegetation types (Patalano et al., 2020). Sterols produce chemical signatures specific to different plant types, and are used to infer palaeovegetation changes, such as shifts from grasses to trees and shrubs, or lacustrine to terrestrial species (Schatz et al., 2011; Schwark et al., 2002; Zech et al., 2010). Analyses of carbon and hydrogen isotopes in these compounds are also used to infer palaeoclimate variability (Patalano et al., 2020; Schirrmacher et al., 2019).

\subsection{Isotope biogeochemistry}

One widely recognized biogeochemical application in archaeology is the analysis of isotopic ratios of strontium, carbon, oxygen, nitrogen, sulphur and other elements in bones and teeth from humans and animals, and the relationship between these and depositional environments. These methods are now routinely used for reconstructing diet, climate, mobility, and environmental changes indicative of anthropogenic modifications to subsistence and habitation strategies (Balasse et al., 2017; Chazin et al., 2019; Demény 
et al., 2019; Giblin and Yerkes, 2016; Makarewicz and Sealy, 2015). For example, stable strontium, oxygen, and carbon isotopes provided evidence for different subgroups of the massacred Neolithic community at Talheim (Bentley et al., 2008). Strontium ratios from Late Neolithic and Copper Age human dental enamel indicate greater variability during the Copper Age on the Great Hungarian Plain, suggesting a wider geographical range of food acquisition (Giblin et al., 2013).

Biochemistry of ancient bone, as in the examples above, typically includes a geological component from the depositional environment. An isotopic study from Czech La Tène cemeteries illustrates the problem of differentiating land-use practices and local geological variability from human mobility when interpreting strontium variability (Scheeres et al., 2014). This highlights the need to map regional baseline isoscapes, or isotopic landscapes, from proxies appropriate for ancient conditions (Bataille et al., 2020; Snoeck et al., 2020).

Sediment biogeochemistry has unrealized potential for reconstructing past human activities and ecosystems (D’Anjou et al., 2012; Vranová et al., 2015; Vranová et al., 2012). A study of $\delta^{15} \mathrm{~N}$ ratios of samples taken from two long-standing agricultural experiments on the impact of manuring on agricultural yields demonstrates that manuring significantly raises nitrogen values in both grains and chaff (Bogaard et al., 2007). Sodium, chlorine, nitrate, and nitratenitrogen isotope values from waste layers at Aşıklı Höyük, a Neolithic tell in central Turkey, were used to calculate increasing numbers of caprines (Abell et al., 2019).

\subsection{Sedimentary ancient DNA}

Ancient human and environmental DNA preserved in palaeosoils can provide evidence for human presence, species identification, and changes in ecological diversity. Sedimentary aDNA (or sedaDNA) can contribute to multiproxy interpretations, but are especially useful when physical remains are not preserved (Brunson and Reich, 2019; Epp et al., 2019; Thomsen and Willerslev, 2015). For example, a study of lake sediments from Poland contrasted humanspecific bacterial DNA, a marker of human faecal material, and pollen counts; results revealed direct correlation of human presence and vegetation changes (Madeja, 2015). Although most recent research has been conducted on lake sediment samples from cores (Giguet-Covex et al., 2014; Madeja, 2015; Parducci et al., 2017), sediment samples can be taken directly from secure archaeological contexts (Hebsgaard et al., 2009; Nejman et al., 2020; Slon et al., 2017).

\subsection{Proteomics from sediments}

Arelatively new area of research in archaeology is proteomics. Proteomics involves the extraction, sequencing, and analysis of proteins that form proteomes, and the identification of species based on the weight of specific proteins; ancient proteomics, or palaeoproteomics, involves the extraction and analysis of proteins from archaeological remains. The application of proteomic methods in archaeology is most developed in the analysis of human and animal bones (Brown et al., 2016; Lanigan et al., 2020), dental calculus (Charlton et al., 2019), and ceramics (Shevchenko et al., 2018). Archaeological and environmental proteomes can also be extracted from soil; preliminary results were promising, but this method is in the early stages of development (Oonk et al., 2012).

\section{Summary: Bringing it all together with multi-proxy approaches}

As we move towards the middle of the $21^{\text {st }}$ century, archaeology departments need to become more interdisciplinary and more attuned to the information stored in the sediment archive: ancient human DNA, other ancient DNA, ancient fats, carbohydrates, and stomach acids, the microbial environment, and changing soil conditions. Bio-geoarchaeology can address new questions, or bring new methods to acquire data that was previously unavailable. Accessing these data requires an acceptance that anthropogenic sediments are archaeological remains.

A couple of points concerning the future development of archaeological soil chemistry must be considered. One is that the latest analytical methods cross disciplinary boundaries and push the current limits of archaeological soil chemistry. Geoarchaeologists will need to integrate knowledge of these methods into their toolkit, without losing their existing expertise. Furthermore, existing methods and protocols may require modification for archaeological contexts, to accommodate the effects of formation processes and the vagaries of human activities. Potential rewards make these efforts worthwhile. Converging lines of evidence from multi-element soil chemistry, magnetic susceptibility, and soil biomarkers will provide greater interpretive power for settlement and activity areas research, whilst also producing complementary evidence for zooarchaeology and other environmental analyses (e.g. Dreslerová et al., 2020; Lauer et al., 2014).

This leads to a second point, which is that our older methods of sampling for inorganic soil chemistry are inadequate for current analytical capabilities. One immediate methodological aim in archaeological soil chemistry should be to establish new and standardized sampling and storage methods for biomarkers, in particular those collected directly from archaeological contexts.

The need for site prospection employing primarily soil phosphate analysis is likely to remain, particularly in woodlands or other conditions that limit geophysics and surface collection. Unfortunately, this approach is rarely used today, despite its obvious application to filling gaps in our survey areas. Portable XRF provides a tool for in field geochemical analysis of geological samples, including soils, that can be done as a prospection method or as biogeochemistry samples are collected. Further, pXRF fits within the budget of most research programmes. In 
these respects, pXRF is both the new state-of-the-art and a method for the future. However, comparisons between institutes or field projects should be undertaken to assess results using standard calibrations, and determine whether correction factors can be developed for general use or need to be established for each individual device. This represents a second essential aim for geoarchaeology. In addition, we need an effective universal protocol for collecting and processing sediment samples in the field, so as not to lose the advantages of speed and portability.

Geoarchaeologists need to be able to collect appropriate samples, and aid in data interpretation, allowing laboratory scientists to develop analytical protocols for sediment bimolecular studies. The combination of biomarkers with geoarchaeological methods such as soil phosphates, magnetic susceptibility, micro-remains, and thin-section analysis will open new frontiers in our understanding of the human past.

\section{Acknowledgements}

I thank two anonymous reviewers for their helpful suggestions, and the Executive Editor for his patience. All omissions are the responsibility of the author.

\section{References}

ABELL, J.T., QUADE, J., DURU, G., MENTZER, S.M., STINER, M.C., UZDURUM, M. and ÖZBASARAN, M., 2019. Urine salts elucidate Early Neolithic animal management at Aşıklı Höyük, Turkey. Science Advances, 5, eaaw0038.

ARRHENIUS, O., 1929. Die Phosphatmethode. Zeitschrift für Pflanzenernährung, Düngung und Bodenkunde, Teil A, 14, 121-140, 185-194.

ARRHENIUS, O., 1931. Die Bodenanalyse im Dienst der Archäologie. Zeitschrift für Pflanzenernährung, Düngung und Bodenkunde, Teil B, 10, 427-439.

ASTON, M., MARTIN, M.H. and JACKSON, A.W., 1998. The use of heavy metal soil analysis for archaeological surveying. Chemosphere, 37, 465-477.

BALASSE, M., BĂLĂŞESCU, A., TORNERO, C., FREMONDEAU, D., HOVSEPYAN, R., GILLIS, R. and POPOVICI, D., 2017. Investigating the scale of herding in Chalcolithic pastoral communities settled along the Danube River in the $5^{\text {th }}$ millennium BC: A case study at BorduşaniPopină and Hârşova-tell (Romania). Quaternary International, 436, Part B, 29-40.

BANDI, H., 1945. Archäologische Erforschung des zukünftigen Stauseegebietes Rossens-Broc. Jahrbuch der Schweizen Gesellschaft für Urgeschichte, 36, 100-106.

BARBA, L. and ORTIZ, A., 1992. Análisis químico de pisos de ocupación Un caso etnográfico en Tlaxcala, Mexico. Latin American Antiquity, 3, 63-82.

BARBA, L., ORTIZ, A., LINK, K., LOPEZ-LUJAN, L. and LAZOS, L., 1996. The chemical analysis of residues in floors and the reconstruction of ritual activities at the Templo Mayor, Mexico. In: M.V. Orna, ed. Archaeological Chemistry: Organic, Inorganic and Biochemical Analysis. Washington, DC: American Chemical Society, pp. 139-156.

BATAILlE, C.P., CROWLEY, B.E., WOOLLER, M.J. and BOWEN, G.J., 2020. Advances in global bioavailable strontium isoscapes. Palaeogeography, Palaeoclimatology, Palaeoecology, 555, 109849.

BENTLEY, R.A., WAHL, J., PRICE, T.D. and ATKINSON, TIM C., 2008. Isotopic signatures and hereditary traits: snapshot of a Neolithic community in Germany. Antiquity, 82, 290-304.
BETHELL, P. and MÁTÉ, I., 1989. The Use of Soil Phosphate Analysis in Archaeology: A Critique. In: J. Henderson, ed. Scientific analysis in archaeology and its interpretation. Los Angeles: UCLA Institute of Archaeology, pp. 1-29.

BETHELL, P.H., GOAD, L.J. and EVERSHED, R.P., 1994. The Study of Molecular Markers of Human Activity: The Use of Coprostanol in the Sol as Indicator of Human Faecal Material. Journal of Archaeological Science, 21, 619-632.

BJELAJAC, V., LUBY, E. and RAY, R., 1996. A Validation Test of a FieldBased Phosphate Analysis Technique. Journal of Archaeological Science, 23, 243-248.

BOGAARD, A., HEATON, T.H.E., POULTON, P. and MERBACH, I., 2007. The impact of manuring on nitrogen isotope ratios in cereals: archaeological implications for reconstruction of diet and crop management practices. Journal of Archaeological Science, 34, 335-343.

BOWEN, H.J.M., 1979. Environmental Chemistry of the Elements, London/ New York: Academic Press.

BROWN, S., HIGHAM, T., SLON, V., PÄÄBO, S., MEYER, M., DOUKA, K., BROCK, F., COMESKEY, D., PROCOPIO, N., SHUNKOV, M., DEREVIANKO, A. and BUCKLEY, M., 2016. Identification of a new hominin bone from Denisova Cave, Siberia using collagen fingerprinting and mitochondrial DNA analysis. Nature: Scientific Reports, 6, 23559.

BRUNSON, K. and REICH, D., 2019. The Promise of Paleogenomics Beyond Our Own Species. Trends in Genetics, 35, 319-329.

BULL, I.D., BERGEN, P.F.V., NOTT, C.J., POULTON, P.R. and EVERSHED, R.P., 2000. Organic geochemical studies of soils from the Rothamsted classical experiments-V. The fate of lipids in different longterm experiments. Organic Geochemistry, 31, 389-408.

BULL, I.D., LOCKHEART, M.J., ELHMMALI, M.M., ROBERTS, D.J. and EVERSHED, R.P., 2002. The origin of faeces by means of biomarker detection. Environment International, 27, 647-654.

BUTLER, D.H., LOPEZ-FORMENT, A. and DAWSON, P.C., 2018. Multielement and biomolecular analyses of soils as a means of sustainable site structure research on hunter-gatherer sites: A case study from the Canadian Arctic. Journal of Archaeological Science: Reports, 17, 973-991.

CHARLTON, S., RAMSØE, A., COLLINS, M., CRAIG, O.E., FISCHER, R., ALEXANDER, M. and SPELLER, C.F., 2019. New insights into Neolithic milk consumption through proteomic analysis of dental calculus. Archaeological and Anthropological Sciences, 11, 6183-6196.

CHAZIN, H., GORDON, G.W. and KNUDSON, K.J., 2019. Isotopic perspectives on pastoralist mobility in the Late Bronze Age South Caucasus. Journal of Anthropological Archaeology, 54, 48-67.

CHRISTENSEN, W., 1935. Jordens Forforsyreindold som Indikator for Tidligere Kultur og Bebyggelse; en Studie af Ermitageslettens Historie, Copenhagen: C.A. Reitzels Forlag.

CONWAY, J.S., 1983. An Investigation of Soil Phosphorus Distribution within Occupation Deposits from a Romano-British Hut Group. Journal of Archaeological Science, 10, 117-128.

CORONEL, E.G., BAIR, D.A., BROWN, C.T. and TERRY, R.E., 2014. Utility and Limitations of Portable X-Ray Fluorescence and Field Laboratory Conditions on the Geochemical Analysis of Soils and Floors at Areas of Known Human Activities. Soil Science, 179, 258-271.

CORONEL, E.G., HUTSON, S., MAGNONI, A., BALZOTTI, C., ULMER, A. and TERRY, R.E., 2015. Geochemical analysis of Late Classic and Post Classic Maya marketplace activities at the Plazas of Cobá, Mexico. Journal of Field Archaeology, 40, 89-109.

D'ANJOU, R.M., BRADLEY, R.S., BALASCIO, N.L. and FINKELSTEIN, D.B., 2012. Climate impacts on human settlement and agricultural activities in northern Norway revealed through sediment biogeochemistry. Proceedings of the National Academy of Sciences, 109, 20332-20337.

DAUNCEY, K.D.M., 1952. Phosphate Content of Soils on Archaeological Sites. Advancement of Science, 9, 33-37.

DEMÉNY, A., KERN, Z., CZUPPON, G., NÉMETH, A., SCHÖLLBARNA, G., SIKLÓSY, Z., LEÉL-ÖSSY, S., COOK, G., SERLEGI, G., BAJNÓCZI, B., SÜMEGI, P., KIRÁLY, Á., KISS, V., KULCSÁR, G. and BONDÁR, M., 2019. Middle Bronze Age humidity and temperature variations, and societal changes in East-Central Europe. Quaternary International, 504, 80-95.

DIETZ, E.F., 1957. Phosphorus Accumulation in Soil of an Indian Habitation Site. American Antiquity, 22, 405-409. 
DREIBRODT, S., FURHOLT, M., HOFMANN, R., HINZ, M. and CHEBEN, I., 2017. P-ed-XRF-geochemical signatures of a 7300-year-old Linear Band Pottery house ditch fill at Vráble-Ve'lké Lehemby, Slovakia - House inhabitation and post-depositional processes. Quaternary International, 438, Part B, 131-143.

DRESLEROVÁ, D., KOZÁKOVÁ, R., METLIČKA, M., BRYCHOVÁ, V., BOBEK, P., ČIŠECKÝ, Č., DEMJÁN, P., LISÁ, L., POKORNÁ, A., MICHÁLEK, J., STROUHALOVÁ, B. and TRUBAČ, J., 2020. Seeking the meaning of a unique mountain site through a multidisciplinary approach. The Late La Tène site at Sklářské Valley, Šumava Mountains, Czech Republic. Quaternary International, 542, 88-108.

DUKE, G.S., VÁSQUEZ-SANCHEZ, V.F. and ROSALES-THAM, T.E., 2018. Starch grain evidence of potato consumption at the Late Moche (AD 600-850) site of Wasi Huachuma, Peru. Journal of Archaeological Science, 100, 74-79.

DUNNE, J., REBAY-SALISBURY, K., SALISBURY, R.B., FRISCH, A., WALTON-DOYLE, C. and EVERSHED, R.P., 2019. Milk of ruminants in ceramic baby bottles from prehistoric child graves. Nature, 574, 246-248.

EIDT, R.C., 1973. A Rapid Chemical Field Test for Archaeological Site Surveying. American Antiquity, 38, 206-210.

EIDT, R.C., 1977. Soil phosphate as a diagnostic feature in abandoned settlement analysis. In: R.C. Eidt, K.N. Singh and R.P.B. Singh, eds. Man, Culture, and Settlement. New Delhi: Kalyani, pp. 216-227.

ENTWISTLE, J.A., DODGSHON, R.A. and ABRAHAMS, P.W., 2000. An investigation of former land-use activity through the physical and chemical analysis of soils from the Isle of Lewis, Outer Hebrides. Archaeological Prospection, 7, 171-188.

EPP, L.S., ZIMMERMANN, H.H. and STOOF-LEICHSENRING, K.R., 2019. Sampling and Extraction of Ancient DNA from Sediments. In: B. Shapiro, A. Barlow, P.D. Heintzman, M. Hofreiter, J.L.A. Paijmans and A.E.R. Soares, eds. Ancient DNA: Methods and Protocols. New York, NY: Springer New York, pp. 31-44.

ERNÉE, M., 2005. Využití fosfátové půdní analýzy při interpretaci kulturního souvrství a zahloubených objektů z mladší a pozdní doby bronzové v Praze 10 - Záběhlicích. The use of soil phosphate analysis in the interpretation of Late and Final Bronze Age cultural stratigraphy and sunken features at Prague 10 - Záběhlice. Archeologické rozhledy, $57,303-330$.

ERNÉE, M. and MAJER, A., 2009. Uniformita, či rozmanitost pohřebního ritu? Interpretace výsledků fosfátové půdní analýzy na pohřebišti únětické kultury v Praze 9 - Miškovicích. Archeologické rozhledy, 61, 493-508.

FANNING, P.C., HOLDAWAY, S.J. and ALLELY, K., 2018. Geoarchaeology in action: A sedimentological analysis of anthropogenic shell mounds from the Cape York region of Australia. Quaternary International, 463, 44-56.

FEIGL, F., 1960. Tüpfelanalyse, Frankfurt am Main: Akademische Verlagsgesselschaft.

FERNÁNDEZ, F.G., TERRY, R.E., INOMATA, T. and EBERL, M., 2002. An ethnoarchaeological study of chemical residues in the floors and soils of Q "eqchi” Maya Houses at Las Pozas, Guatemala. Geoarchaeology, $17,487-519$.

FRAHM, E., MONNIER, G.F., JELINSKI, N.A., FLEMING, E.P., BARBER, B.L. and LAMBON, J.B., 2016. Chemical soil surveys at the Bremer Site (Dakota county, Minnesota, USA): Measuring phosphorous content of sediment by portable XRF and ICP-OES. Journal of Archaeological Science, 75, 115-138.

FÜLEKY, G., 1983. Fontosabb hazai talajtípusok foszforállapota. Agrokémia és Talajtan, 32, 7-30.

GAUSS, R.K., BÁTORA, J., NOWACZINSKI, E., RASSMANN, K. and SCHUKRAFT, G., 2013. The Early Bronze Age settlement of Fidvár, Vráble (Slovakia): reconstructing prehistoric settlement patterns using portable XRF. Journal of Archaeological Science, 40, 2942-2960.

GEBHARDT, H., 1982. Phosphatkartierung und bodenkundliche Geländeuntersuchungen zur Eingrenzung historischer Siedlungs- und Wirtschaftsflächen des Geestinsel Flögeln, Kreis Cuxhaven. Probleme der Küstenforschung im südlichen Nordseegebiet, 14, 1-9.

GIBLIN, J.I., KNUDSON, K.J., BERECZKI, Z., PÁLFI, G. and PAP, I., 2013. Strontium isotope analysis and human mobility during the Neolithic and Copper Age: a case study from the Great Hungarian Plain. Journal of Archaeological Science, 40, 227-239.
GIBLIN, J.I. and YERKES, R.W., 2016. Diet, dispersal and social differentiation during the Copper Age in eastern Hungary. Antiquity, 90, 81-94.

GIGUET-COVEX, C., PANSU, J., ARNAUD, F., REY, P.-J., GRIGGO, C., GIELLY, L., DOMAIZON, I., COISSAC, E., DAVID, F., CHOLER, P., POULENARD, J. and TABERLET, P., 2014. Long livestock farming history and human landscape shaping revealed by lake sediment DNA. Nature Communications, 5, 3211.

GOFF, K., SCHAETZL, R.J., CHAKRABORTY, S., WEINDORF, D.C., KASMERCHAK, C. and BETTIS III, E.A., 2020. Impact of sample preparation methods for characterizing the geochemistry of soils and sediments by portable X-ray fluorescence. Soil Science Society of America Journal, 84, 131-143.

GOJDA, M. and HEJCMAN, M., 2012. Cropmarks in main field crops enable the identification of a wide spectrum of buried features on archaeological sites in Central Europe. Journal of Archaeological Science, 39, 1655-1664.

GRIMM, P., 1971. Phosphatuntersuchungen in der Wüstung Hohenrode bei Grillenhberg, Kr. Saugerhausen. Ausgrabungen und Funde, 16, 43-49.

GUNDLACH, H., 1961. Tüpfelmethode auf Phosphat, angewandt in prähistorischer Forschung (als Feldmethode). Microchimica Acta, 5, 734-737.

GYUCHA, A., YERKES, R.W., PARKINSON, W.A., PAPADOPOULOS, N., SARRIS, A., DUFFY, P.R. and SALISBURY, R.B., 2015. Settlement Nucleation in the Neolithic: A Preliminary Report of the Körös Regional Archaeological Project's Investigations at Szeghalom-Kovácshalom and Vésztő-Mágor. In: S. Hansen, P. Raczky, A. Anders and A. Reingruber, eds. Neolithic and Copper Age between the Carpathians and the Aegean Sea. Chronologies and Technologies from the $6^{\text {th }}$ to the $4^{\text {th }}$ Millennium BCE. International Workshop Budapest 2012. Bonn: Dr. Rudolf Habelt, pp. $129-142$.

HARRAULT, L., MILEK, K., JARDÉ, E., JEANNEAU, L., DERRIEN, M. and ANDERSON, D.G., 2019. Faecal biomarkers can distinguish specific mammalian species in modern and past environments. PLOS ONE, 14, e0211119.

HASLAM, R. and TIBBETT, M., 2004. Sampling and analyzing metals in soils for archaeological prospection: A critique. Geoarchaeology, 19, 731-751.

HEBSGAARD, M.B., GILBERT, M.T.P., ARNEBORG, J., HEYN, P., ALLENTOFT, M.E., BUNCE, M., MUNCH, K., SCHWEGER, CH. and WILLERSLEV, E., 2009. "The Farm Beneath the Sand" - an archaeological case study on ancient "dirt" DNA. Antiquity, 83, 430-444.

HEJCMAN, M., ONDRÁČEK, J. and SMRZ̆, Z., 2011. Ancient waste pits with wood ash irreversibly increase crop production in Central Europe. Plant and Soil, 339, 341-350.

HEJCMAN, M. and SMRŽ, Z., 2010. Cropmarks in stands of cereals, legumes and winter rape indicate sub-soil archaeological features in the agricultural landscape of Central Europe. Agriculture, Ecosystems and Environment, 138, 348-354.

HEJCMAN, M., SOUČKOVÁ, K. and GOJDA, M., 2013a. Prehistoric settlement activities changed soil $\mathrm{pH}$, nutrient availability, and growth of contemporary crops in Central Europe. Plant and Soil, 369, 131-140.

HEJCMAN, M., SOUČKOVÁ, K., KRIŠTUF, P. and PEŠKA, J., 2013b. What questions can be answered by chemical analysis of recent and paleosols from the Bell Beaker barrow (2500-2200 BC), Central Moravia, Czech Republic? Quaternary International, 316, 179-189.

HJULSTRÖM, B. and ISAKSSON, S., 2009. Identification of activity area signatures in a reconstructed Iron Age house by combining element and lipid analyses of sediments. Journal of Archaeological Science, 36, 174-183.

HLAVICA, M., PETŘíK, J., PROKEŠ, L. and ŠABATOVÁ, K., 2011. Evaluation of Phosphate Analysis and the Brongers Method of Detecting Decomposed Wood, Human Tissue and Organic Goods in a Bell Beaker Grave at Těšetice-Kyjovice, Czech Republic. Interdisciplinaria Archaeologica, Natural Sciences in Archaeology, 2(2), 85-94.

HOLCOMB, J.A. and KARKANAS, P., 2019. Elemental mapping of micromorphological block samples using portable X-ray fluorescence spectrometry (pXRF): Integrating a geochemical line of evidence. Geoarchaeology, 34, 613-624.

HOLLIDAY, V.T., 2004. Soils in Archaeological Research, Oxford: Oxford University Press. 
HOLLIDAY, V., LAWRENCE-ZUNIGA, D. and BUCHLI, V., 2010 Prologue to Uses of Chemical Residues to Make Statements About Human Activities. Journal of Archaeological Method and Theory, 17, $175-182$.

HOLLIDAY, V.T. and GARTNER, W.G., 2007. Methods of soil P analysis in archaeology. Journal of Archaeological Science, 34, 301-333.

HORÁK, J., JANOVSKÝ, M., HEJCMAN, M., ŠMEJDA, L. and KLÍR, T., 2018. Soil geochemistry of medieval arable fields in Lovětín near Třešt', Czech Republic. CATENA, 162, 14-22.

JANOVSKÝ, M. and HORÁK, J. 2018. Large Scale Geochemical Signatures Enable to Determine Landscape Use in the Deserted Medieval Villages. Interdisciplinaria Archaeologica, Natural Sciences in Archaeology, 9(1), 71-80.

KABATA-PENDIAS, A. and PENDIAS, H., 1984. Trace Elements in Soils and Plants, Boca Raton, FL: CRC Press.

KEELEY, H.C.M., 1981. Recent Work using Soil Phosphorus Analysis in Archaeological Prospection. Revue d'Archéométrie, 5, 89-95.

KIEFMANN, H.-M., 1979. Die Phosphatmethode - Ergebnisse neuerer Untersuchungen. Geografiska Annaler. Series B, Human Geography, 61, $1-7$.

KILLOPS, S. and KILLOPS, V., 2005. Introduction to Organic Geochemistry, London/New York: Wiley-Blackwell.

KINTIGH, K., ALTSCHUL, J., BEAUDRY, M., DRENNAN, R., KINZIG, A., KOHLER, T., LIMP, W.F., MASCHNER, H., MICHENER, W., PAUKETAT, T., PEREGRINE, P., SABLOFF, J., WILKINSON, T., WRIGHT, H. and ZEDER, M., 2014. Grand Challenges for Archaeology. American Antiquity, 79, 5-24.

KLAMM, M., WEBER, T. and WUNDERLICH, C.-H., 1998. Zur Phosphatmethode in der Archäologie. Reflektometrische Bestimmung von Phosphat auf archäologischen Grabungen, Mainz: RömischGermanisches Zentralmuseum.

KNUDSON, K.J. and FRINK, L., 2010. Ethnoarchaeological analysis of Arctic fish processing: chemical characterization of soils on Nelson Island, Alaska. Journal of Archaeological Science, 37, 769-783.

KNUDSON, K.J., FRINK, L., HOFFMAN, B.W. and PRICE, T.D., 2004. Chemical characterization of Arctic soils: activity area analysis in contemporary Yup'ik fish camps using ICP-AES. Journal of Archaeological Science, 31, 443-456.

KONDRATIUK, P. and BANASZUK, P., 1993. Interpretation of phosphorus concentration in archaeology in the light of soil science research. Archaeologia Polona, 31, 141-147.

KOVALEVA, N.O. and KOVALEV, I.V., 2015. Lignin phenols in soils as biomarkers of paleovegetation. Eurasian Soil Science, 48, 946-958.

KRISTIANSEN, K., 2014. Towards a New Paradigm: The Third Science Revolution and its Possible Consequences in Archaeology (including comments). Current Swedish Archaeology, 22, 11-71.

LANIGAN, L.T., MACKIE, M., FEINE, S., HUBLIN, J.-J., SCHMITZ, R.W., WILCKE, A., COLLINS, M.J., CAPPELLINI, E., OLSEN, J.V, TAUROZZI, A.J. and WELKER, F., 2020. Multi-protease analysis of Pleistocene bone proteomes. Journal of Proteomics, 103889.

LAUER, F., PÄTZOLD, S., GERLACH, R., PROTZE, J., WILLBOLD, S. and AMELUNG, W., 2013. Phosphorus status in archaeological arable topsoil relicts - Is it possible to reconstruct conditions for prehistoric agriculture in Germany? Geoderma, 207-208, 111-120.

LAUER, F., PROST, K., GERLACH, R., PÄTZOLD, S., WOLF, M., URMERSBACH, S., LEHNDORFF, E., ECKMEIER, E. an AMELUNG, W., 2014. Organic Fertilization and Sufficient Nutrient Status in Prehistoric Agriculture? - Indications from Multi-Proxy Analyses of Archaeological Topsoil Relicts. PLoS ONE, 9, e106244.

LEONARDI, G., MIGLAVACCA, M. and NARDI, S., 1999. Soil Phosphorus Analysis as an Integrative Tool for Recognizing Buried Ancient Ploughsoils. Journal of Archaeological Science, 26, 343-352.

LORCH, W., 1930. Neue Methoden der Siedlungsgeschichte. Geographische Zeitschrift, 45, 294-305.

LORCH, W., 1940. Die siedlungsgeographische Phosphatmethode. Die Naturwissenschaften, 28, 633-640.

LORCH, W., 1941. Chemische Spuren im Boden als Zeichen früherer menschlicher Besiedlung. Die Umschau in Wissenschaft und Technik, 45 , $116-120$.

LORCH, W., 1951. Die Entnahme von Bodenproben und ihre Einsendung zur Untersuchung mittels der siedlungsgeschichtlichen Phosphatmethode.
Die Kunde, N.F., 2, 21-23.

LUBOS, C., DREIBRODT, S. and BAHR, A., 2016. Analysing spatiotemporal patterns of archaeological soils and sediments by comparing pXRF and different ICP-OES extraction methods. Journal of Archaeological Science: Reports, 9, 44-53.

LUTZ, H.J., 1951. The concentration of certain chemical elements in the soils of Alaskan archaeological sites. American Journal of Science, 249, 925-928.

MADEJA, J., 2015. A new tool to trace past human presence from lake sediments: the human-specific molecular marker Bacteroides strain HF 183. Journal of Quaternary Science, 30, 349-354.

MAJER, A., 1984. Relativní metoda fosfátové půdní analýzy. Archeologické rozhledy, 36, 297-313.

MAJER, A., 2004. Geochemie v archeologii. In: M. Kuna, ed. Nedestruktivni archeologie. Teorie, metody a cille-Non-destructive archaeology. Theory, methods and goals. Praha: Academia, pp. 195-235.

MAKAREWICZ, C.A. and SEALY, J., 2015. Dietary reconstruction, mobility, and the analysis of ancient skeletal tissues: Expanding the prospects of stable isotope research in archaeology. Journal of Archaeological Science, 56, 146-158.

MARKIEWICZ, M. and REMBISZ-LUBIEJEWSKA, A., 2016. Evidence of a homestead from the Late Bronze Age at the Ruda site (Northern Poland) based on archaeopedological studies. Bulletin of Geography. Physical Geography Series, 11, 71-81.

MARTÍNEZ CORTIZAS, A., LÓPEZ-MERINO, L., BINDLER, R., MIGHALL, T. and KYLANDER, M.E., 2016. Early atmospheric metal pollution provides evidence for Chalcolithic/Bronze Age mining and metallurgy in Southwestern Europe. Science of The Total Environment, 545-546, 398-406.

MICHAŁOWSKI, A., NIEDZIELSKI, P., KOZAK, L., TESKA, M., JAKUBOWSKI, K. and ŻÓŁKIEWSKI, M., 2020. Archaeometrical studies of prehistoric pottery using portable ED-XRF. Measurement, 159, 107758.

MIDDLETON, W.D., 2004. Identifying Chemical Activity Residues on Prehistoric House Floors: A Methodology and Rationale for MultiElemental Characterization of a Mild Acid Extract of Anthropogenic Sediments. Archaeometry, 46, 47-65.

MIDDLETON, W.D. and PRICE, T.D., 1996. Identification of Activity Areas by Multi- element Characterization of Sediments from Modern and Archaeological House Floors Using Inductively Coupled Plasma-Atomic Emission Spectroscopy. Journal of Archaeological Science, 23, 673-687.

MURPHY, J. and RILEY, J.P., 1962. A modified single solution method for the determination of phosphate in natural waters. Analytica Chemica Acta, 27, 31-36.

NEJMAN, L., HUGHES, P., SULLIVAN, M., WRIGHT, D., WAY, A., SKOPAL, W., MLEJNEK, O., ŠKRDLA, P., LISÁ, L., KMOŠEK, M., NÝVLTOVÁ FIŠÁKOVÁ, M., KRALIK, M., NERUDA, P., NERUDOVÁ, Z. and PŘICHYSTAL, A. 2020. Preliminary Report of the 2019 Excavation at Švédův Stůl Cave in the Moravian Karst. Přehled výzkumů, 61, 11-19.

NEJMAN, L., LISÁ, L., DOLÁKOVÁ, N., HORÁČEK, I., BAJER, A., NOVÁK, J., WRIGHT, D., SULLIVAN, M., WOOD, R., GARGETT, R. H., PACHER, M., SÁZELOVÁ, S., NÝVLTOVÁ FIŠÁKOVÁ, M., ROHOVEC, J. and KRÁLÍK, M. 2018. Cave Deposits as a Sedimentary Trap for the Marine Isotope Stage 3 Environmental Record: The Case Study of Pod Hradem, Czech Republic. Palaeogeography, Palaeoclimatology, Palaeoecology, 497, 201-217.

NICOLL, K. and MURPHY, L.R., 2014. Soil and sediment archives of ancient landscapes, paleoenvironments, and archaeological site formation processes. Quaternary International, 342, 1-4.

NORD, A., TRONNER, K., MATTSSON, E., BORG, G. and ULLÉN, I., 2005. Environmental Threats to Buried Archaeological Remains. Ambio, $34,256-62$

NUÑEZ, M. and VINBERG, A., 1990. Determinations of anthropic soil phosphate on Åland. Norwegian Archaeological Review, 23, 93-104.

OONK, S., CAPPELLINI, E. and COLLINS, M.J., 2012. Soil proteomics: An assessment of its potential for archaeological site interpretation. Organic Geochemistry, 50, 57-67.

OONK, S., SLOMP, C.P. and HUISMAN, D.J., 2009a. Geochemistry as an Aid in Archaeological Prospection and Site Interpretation: Current Issues and Research Directions. Archaeological Prospection, 16, 35-51. 
OONK, S., SLOMP, C.P., HUISMAN, D.J. and VRIEND, S.P., 2009 b. Effects of site lithology on geochemical signatures of human occupation in archaeological house plans in the Netherlands. Journal of Archaeological Science, 36, 1215-1228.

PANKOWSKÁ, A., MONÍK, M. and NECHVÁTAL, M., 2018. Reading the Silhouettes of Burnt Dead: Using Elemental Analysis (pXRF) to Identify Late Bronze and Early Iron Age Urn Cenotaphs at Ostrov u Stříbra Site (Czech Republic). Anthropologie (Brno), 56, 39-52.

PARDUCCI, L., BENNETT, K.D., FICETOLA, G.F., ALSOS, I.G., SUYAMA, Y., WOOD, J.R. and PEDERSEN, M.W., 2017. Ancient plant DNA in lake sediments. New Phytologist, 214, 924-942.

PARKINSON, W.A., GYUCHA, A., YERKES, R.W., MORRIS, M.R., SARRIS, A. and SALISBURY, R.B., 2010. Early Copper Age Settlements in the Körös Region of the Great Hungarian Plain. Journal of Field Archaeology, 35, 164-183.

PASTOR, A., GALLELlO, G., CERVERA, M.L. and DE LA GUARDIA, M., 2016. Mineral soil composition interfacing archaeology and chemistry. TrAC Trends in Analytical Chemistry, 78, 48-59.

PATALANO, R., ZECH, J. and ROBERTS, P., 2020. Leaf Wax Lipid Extraction for Archaeological Applications. Current Protocols in Plant Biology, 5, e20114.

PELIKÁN, J.B., 1954. Chemický posudek k výzkumu v Brodcích n. J. v roce 1953. Památky archeologické, 45, 324-328.

PETÖ, Á., KENÉZ, Á., PRUNNER, A.C. and LISZTES-SZABÓ, Z., 2015. Activity area analysis of a Roman period semi-subterranean building by means of integrated archaeobotanical and geoarchaeological data. Vegetation History and Archaeobotany, 24, 101-120.

PETÖ, Á., NIEBIESZCZAŃSKI, J., SERLEGI, G., JAEGER, M. and KULCSÁR, G., 2019. The site mapping of Kakucs-Turján by the means of horizontal and vertical proxies: Combining field and basic laboratory methods of geoarchaeology and archaeological prospection. Journal of Archaeological Science: Reports, 27, 101999.

PETŘÍK, J., PROKEŠ, L., HUMPOLA, D., FAJKOŠOVÁ, Z., KUČA, M., ŠABATOVÁ, K. and KAZDOVÁ, E., 2012. Pedogeochemical Investigation of Bell Beaker Culture Graves from Hodonice and TěšeticeKyjovice, Moravia, Czech Republic. In: J. Kolár and F. Trampota, eds. Theoretical and Methodological Considerations in Central European Neolithic Archaeology Proceedings of the "Theory and Method in Archaeology of the Neolithic $\left(7^{\text {th }}-3^{\text {rd }}\right.$ millennium BC)" conference held in Mikulov, Czech Republic, $26^{\text {th }}-28^{\text {th }}$ of October 2010. Oxford: Archaeopress, British Archaeological Reports, pp. 45-64.

PORTILLO, M., GARCÍA-SUÁREZ, A. and MATTHEWS, W., 2020. Livestock faecal indicators for animal management, penning, foddering and dung use in early agricultural built environments in the Konya Plain, Central Anatolia. Archaeological and Anthropological Sciences, 12, 40.

PROST, K., BIRK, J.J., LEHNDORFF, E., GERLACH, R. and AMELUNG, W., 2017. Steroid Biomarkers Revisited - Improved Source Identification of Faecal Remains in Archaeological Soil Material. PLoS ONE, 12, e0164882-e0164882.

RIEBE, D.J., 2019. Sourcing Obsidian from Late Neolithic Sites on the Great Hungarian Plain: Preliminary p-XRF Compositional Results and the Socio-Cultural Implications. Interdisciplinaria Archaeologica, Natural Sciences in Archaeology, 10(2), 113-120.

RIEBE, D.J. and NIZIOLEK, L.C., 2015. Investigating Compositional Variation of Ceramic Materials during the Late Neolithic on the Great Hungarian Plain - Preliminary LA-ICP-MS Results. Open Geosciences, 7, 426-445.

ROTS, V., HARDY, B.L., SERANGELI, J. and CONARD, N.J., 2015. Residue and microwear analyses of the stone artefacts from Schöningen. Journal of Human Evolution, 89, 298-308.

RUSSELL, E.J., 1915. The Fertility of the Soil, Cambridge: Cambridge University Press.

SALISBURY, R.B., 2012. Soilscapes and settlements: remote mapping of activity areas in unexcavated small farmsteads. Antiquity, 86, 178-190.

SALISBURY, R.B., 2013. Interpolating geochemical patterning of activity zones at Late Neolithic and Early Copper Age settlements in eastern Hungary. Journal of Archaeological Science, 40, 926-934.

SALISBURY, R.B., 2016. Soilscapes in Archaeology: Settlement and Social Organization in the Neolithic of the Great Hungarian Plain, Budapest: Archaeolingua.

SALISBURY, R.B., 2017. Links in the chain: evidence for crafting and activity areas in late prehistoric cultural soilscapes. In: A. Gorgues, K. Rebay-Salisbury and R.B. Salisbury, eds. Material chains in late prehistoric Europe and the Mediterranean: time, space, and technologies of production. Bordeaux: Ausonius Éditions, pp. 47-65.

SALISBURY, R.B., BERTÓK, G. and BÁCSMEGI, G., 2013. Integrated Prospection Methods to Define Small-site Settlement Structure: A Case Study from Neolithic Hungary. Archaeological Prospection, 20, 1-10.

SARRIS, A., GALATY, M.L., YERKES, R.W., PARKINSON, W.A., GYUCHA, A., BILLINGSLEY, D.M. and TATE, R., 2004. Geophysical prospection and soil chemistry at the Early Copper Age settlement of Vésztõ-Bikeri, Southeastern Hungary. Journal of Archaeological Science, 31, 927-939.

SCHATZ, A.-K., ZECH, M., BUGGLE, B., GULYÁS, S., HAMBACH, U., MARKOVIC, S.B., SÜMEGI, P. and SCHOLTEN, T., 2011. The late Quaternary loess record of Tokaj, Hungary: Reconstructing palaeoenvironment, vegetation and climate using stable $\mathrm{C}$ and $\mathrm{N}$ isotopes and biomarkers. Quaternary International, 240, 52-61.

SCHEERES, M., KNIPPER, C., HAUSCHILD, M., SCHÖNFELDER, M., SIEBEL, W., PARE, C. and ALT, K.W., 2014. "Celtic migrations": Fact or fiction? Strontium and oxygen isotope analysis of the Czech cemeteries of Radovesice and Kutná Hora in Bohemia. American Journal of Physical Anthropology, 155, 496-512.

SCHIRRMACHER, J., WEINELT, M., BLANZ, T., ANDERSEN, N., SALGUEIRO, E. and SCHNEIDER, R.R., 2019. Multi-decadal atmospheric and marine climate variability in southern Iberia during the mid- to late-Holocene. Climate of the Past, 15, 617-634.

SCHNELL, I., 1932. Strandlingebestamingar och Markanalys. Fornvännen, $27,40-47$.

SCHREG, R. and BEHRENDT, S., 2011. Phosphatanalysen in einem frühmittelalterlichen Haus in Schalkstetten (Gemeinde Amstetten, AlbDonau-Kreis). Archäologisches Korrespondenzblatt, 41, 263-272.

SCHUMACHER, M., SCHIER, W. and SCHÜTT, B., 2016. Mid-Holocene vegetation development and herding-related interferences in the Carpathian region. Quaternary International, 415, 253-267.

SCHWARK, L., ZINK, K. and LECHTERBECK, J., 2002. Reconstruction of postglacial to early Holocene vegetation history in terrestrial Central Europe via cuticular lipid biomarkers and pollen records from lake sediments. Geology, 30, 463-466.

SCHWARTZ, G.T., 1967. A simplified chemical test for archaeological field work. Archaeometry, 10, 57-63.

SHEVCHENKO, A., SCHUHMANN, A., THOMAS, H. and WETZEL, G., 2018. Fine Endmesolithic fish caviar meal discovered by proteomics in foodcrusts from archaeological site Friesack 4 (Brandenburg, Germany). PLoS ONE, 13, e0206483.

SIMPSON, I.A., VAN BERGEN, P.F., PERRET, V., ELHMMALI, M.M., ROBERTS, D.J. and EVERSHED, R.P., 1999. Lipid biomarkers of manuring practice in relict anthropogenic soils. The Holocene, 9, 223-229.

SISTIAGA, A., MALLOL, C., GALVÁN, B. and SUMMONS, R.E., 2014. The Neanderthal Meal: A New Perspective Using Faecal Biomarkers. PLoS ONE, 9, e101045.

SJÖBERG, A., 1976. Phosphate Analysis of Anthropic Soils. Journal of Field Archaeology, 3, 447-454.

SLON, V., HOPFE, C., WEISS, C.L., MAFESSONI, F., DE LA RASILLA, M., LALUEZA-FOX, C., ROSAS, A., SORESSI, M., KNUL, M.V., MILLER, R., STEWART, J.R., DEREVIANKO, A.P., JACOBS, Z., LI, B., ROBERTS, R.G., SHUNKOV, M.V., DE LUMLEY, H., PERRENOUD, C., GUŠIĆ, I., KUĆAN, Ž., RUDAN, P., AXIMU-PETRI, A., ESSEL, E., NAGEL, S., NICKEL, B., SCHMIDT, A., PRÜFER, K., KELSO, J., BURBANO, H.A., PÄÄBO, S. and MEYER, M., 2017. Neandertal and Denisovan DNA from Pleistocene sediments. Science, 356, 605-608.

ŠMEJDA, L., HEJCMAN, M., HORÁK, J. and SHAI, I., 2017. Ancient settlement activities as important sources of nutrients $(\mathrm{P}, \mathrm{K}, \mathrm{S}, \mathrm{Zn}$ and $\mathrm{Cu}$ ) in Eastern Mediterranean ecosystems - The case of biblical Tel Burna, Israel. CATENA, 156, 62-73.

ŠMEJDA, L., HEJCMAN, M., HORÁK, J. and SHAI, I., 2018. Multielement mapping of anthropogenically modified soils and sediments at the Bronze to Iron Ages site of Tel Burna in the southern Levant. Quaternary International, 483, 111-123.

SNOECK, C., RYAN, S., POUNCETT, J., PELLEGRINI, M., CLAEYS, P., WAINWRIGHT, A.N., MATTIELLI, N., LEE-THORP, J.A. and 
SCHULTING, R.J., 2020. Towards a biologically available strontium isotope baseline for Ireland. Science of The Total Environment, 712, 136248.

SPARKS, D.L. (ed.), 1996. Methods of Soil Analysis. Part 3: Chemical Methods, Madison, WI: Soil Science Society of America.

SPARKS, D.L., 2003. Environmental Soil Chemistry, Amsterdam: Academic Press.

SPOSITO, G., 1998. Bodenchemie, Stuttgart: Enke.

SPRAFKE, T., 2016. Löss in Niederösterreich - Archiv quartärer Klimaund Landschaftsveränderungen. Loess in Lower Austria - archive of Quaternary climate and landscape changes. Würzburg: Würzburg University Press.

STÄUBLE, H. and LÜNING, J., 1999. Phosphatanalysen in bandkeramischen Häusern. Archäologisches Korrespondenzblatt, 29, $165-187$.

STOYE, K., 1950. Die Anwendung der Phosphatmethode auf einem mittelalterlichen Friedhof. Jahresschrift für Mitteldeutsche Vorgeschichte, 34, 180-184.

TERRY, R.E., BAIR, D.A. and CORONEL, E.G., 2015. Soil Chemistry in the Search for Ancient Maya Marketplaces. In: E.M. King, ed. The Ancient Maya Marketplace. Tucson, AZ: University of Arizona Press, pp. $138-167$.

TERRY, R.E., FERNÁNDEZ, F.G., PARNELL, J.J. and INOMATA, T., 2004. The story in the floors: chemical signatures of ancient and modern Maya activities at Aguateca, Guatemala. Journal of Archaeological Science, 31, 1237-1250.

THOMSEN, P.F. and WILLERSLEV, E., 2015. Environmental DNA - An emerging tool in conservation for monitoring past and present biodiversity. Biological Conservation, 183, 4-18.

THURSTON, T.L., 2001. Landscapes of Power, Landscapes of Conflict: State Formation in the Danish Iron Age, New York: Kluwer Academic/ Plenum Publishing.

VERON, A., NOVAK, M., BRIZOVA, E. and STEPANOVA, M., 2014 Environmental Imprints of Climate Changes and Anthropogenic Activities in the Ore Mountains of Bohemia (Central Europe) since 13 Cal. Kyr Bp. The Holocene, 24, 919-931.

VIANELLO, A. and TYKOT, R.H., 2017. Investigating Technological Changes in Copper-Based Metals Using Portable XRF Analysis. A Case Study in Sicily. Open Archaeology, 3, 392.

VRANOVÁ, V., MARFO, T.D. and REJŠEK, K., 2015. Soil Scientific Research Methods Used in Archaeology - Promising Soil Biochemistry: A Mini-review. Acta Universitatis Agriculturae et Silviculturae Mendelianae Brunensis, 63, 1417-1426.

VRANOVÁ, V., ZAHRADNICKOVA, H., JANOUS, D., SKENE, K.R. MATHARU, A.S., REJŠEK, K. and FORMANEK, P., 2012. The significance of D-amino acids in soil, fate and utilization by microbes and plants: review and identification of knowledge gaps. Plant and Soil 354, 21-39.

WALKER, R., 1992. Phosphate survey: Method and meaning. In: P. Spoerry, ed. Geoprospection in the Archaeological Landscape. Oxford: Oxbow Books, pp. 61-73.

WEIHRAUCH, C., BRANDT, I. and OPP, C., 2017. Die archäologische Aussagekraft von Phosphatprospektionen auf gedüngten landwirtschaftlichen Nutzflächen - eine Fallstudie im Gebiet Sievern (Ldkr. Cuxhaven). Archäologische Informationen, 40, 279-290.

WEIHRAUCH, C. and SÖDER, U., 2020. On the Challenges of Soil Phosphorus Prospections in Heterogeneous Environments - a Case Study on the Iron Age Altenburg Hillfort (Niedenstein, Hesse, Germany) Journal of Archaeological Method and Theory. DOI: 10.1007/s10816020-09461-y

WEIHRAUCH, C., SOEDER, U., OPP, C. and SCHUPP, A., 2020 Could oxalate-extractable phosphorus replace phosphorus fractionation schemes in soil phosphorus prospections? A case study in the prehistoric Milseburg hillfort (Germany). Geoarchaeology, 35, 98-111.

WELLS, E.C., 2004a. A Brief History of Archaeological Soil Chemistry. Newsletter of the Commission on the History, Philosophy, and Sociology of Soil Science of the IUSS, 11, 2-4.
WELLS, E.C., 2004b. Investigating Activity Patterns in Prehispanic Plazas: Weak Acid-Extraction ICP-AES Analysis of Anthrosols at Classic Period El Coyote, North-western Honduras. Archaeometry, 46, 67-84.

WELLS, E.C., 2006. Cultural soilscapes. In: E. Frossard, W.E.H. Blum and B.P. Warkentin, eds. Function of soils for human societies and the environment. Geological Society, London, Special Publications. London: Geological Society, pp. 125-132.

WELLS, E.C. and URBAN, P.A., 2002. An Ethnoarchaeological Perspective on the Material and Chemical Residues of Communal Feasting at El Coyote, Northwest Honduras. In: P. Vandiver, M. Goodway and J. Mass, eds. Materials Issues in Art and Archaeology VI. Warrendale, PA: Materials Research Society, pp. 193-198.

WILLERSLEV, E., HANSEN, A.J., BINLADEN, J., BRAND, T.B., GILBERT, M.T.P., SHAPIRO, B., BUNCE, M., WIUF, C., GILICHINSKY, D.A. and COOPER, A., 2003. Diverse Plant and Animal Genetic Records from Holocene and Pleistocene Sediments. Science, 300, 791-795.

WILSON, C.A., CRESSER, M.S. and DAVIDSON, D.A., 2006. Sequential element extraction of soils from abandoned farms: an investigation of the partition of anthropogenic element inputs from historic land use. Journal of Environmental Monitoring, 8, 439-444.

WILSON, C.A., DAVIDSON, D.A. and CRESSER, M.S., 2008. Multielement soil analysis: An assessment of its potential as an aid to archaeological interpretation. Journal of Archaeological Science, 35, $412-424$

WILSON, C.A., DAVIDSON, D.A. and CRESSER, M.S., 2009. An evaluation of the site specificity of soil elemental signatures for identifying and interpreting former functional areas. Journal of Archaeological Science, 36, 2327-2334.

ZECH, M., BUGGLE, B., LEIBER, K., MARKOVIĆ, S., GLASER, B., HAMBACH, U., HUWE, B., STEVENS, T., SÜMEGI, P., WIESENBERG, G. and ZÖLLER, L., 2010. Reconstructing Quaternary vegetation history in the Carpathian Basin, SE-Europe, using n-alkane biomarkers as molecular fossils: Problems and possible solutions, potential and limitations. $E \& G$ Quaternary Science Journal, 58, 148-155.

ZIMMERMANN, W.H., 1995. Haus, Hof und Siedlungsstruktur auf der Geest vom Neolithikum bis in das Mittelalter. In: H.-E. Dannenberg and H.-J. Schulze, eds. Geschichte des Landes zwischen Elbe und Weser. Stade: Landschaftsverband der Ehemaligen Herzogtümer Bremen und Verden, pp. 251-288.

ZIMMERMANN, W.H., 2001. Phosphatkartierung mit großem und kleinem Probenraster in der Siedlungsarchäologie. Ein Erfahrungsbericht. Phosphate mapping with large and small sample intervals used for settlement archaeology. A report on the observations. In: ,...Trans Albim Fluvium". Forschungen zur vorrömischen, kaiserzeitlichen und mittelalterlichen Archäologie. Festschrift für Achim Leube. Internationale Archäologie, Studia honoria, 10. Rahden/Westfalen, pp. 69-79.

ZIMMERMANN, W.H., 2008. Phosphate mapping of a Funnel Beaker Culture house from Flögeln-Eekhöltjen, district of Cuxhaven, Lower Saxony. Analecta Praehistorica Leidensia, 40, 123-129.

ZOCATELLI, R., LAVRIEUX, M., GUILLEMOT, T., CHASSIOT, L., LE MILBEAU, C. and JACOB, J., 2017. Faecal biomarker imprints as indicators of past human land uses: Source distinction and preservation potential in archaeological and natural archives. Journal of Archaeological Science, 81, 79-89.

ZÖLITZ, R., 1980. Bodenphosphat als Siedlungsindikator. Möglichkeiten und Grenzen der siedlungsgeogaphischen und archäologischen Phosphatmethode, Offa: Neumünster.

ZÖLITZ, R., 1982. Geographische Siedlungsprospektion in Schleswig Holstein. Archäologiches Korrespondenzblatt, 12, 517-533.

ZÖLITZ, R., 1983. Bodenchemische Untersuchungen im Bereich vor- und frühgeschichtlicher Siedlungen. Schriften des Naturwissenschaftlichen Vereins für Schleswig - Holstein, 53, 33-57.

ZÖLITZ, R., 1986. Phosphatuntersuchungen zur Siedlungsprospektion in der Gemarkung Kosel (Kreis Rendsburg - Eckförde). Bericht der Römisch-Germanisch Kommission, 67, 454-464.

ZÖLITZ, R. and HEINRICH, U., 1990. Methodische Anmerkungen zur siedlungsarchäologischen Phosphatanalyse. Archäophysika, 12, 383-408. 
